\title{
Research on the Reform and Innovation of Practical Teaching Mode for English Education Major
}

\author{
Wang Juan \\ School of Foreign Language, Yangtze University, Jingzhou, Hubei, P. R. China.
}

Type of Work: Peer-Reviewed

DOl: http://dx.doi.org/10.21013/jems.v15.n4.p7

\section{How to cite this paper:}

Juan, Wang. (2019). Research on the Reform and Innovation of Practical Teaching Mode for English Education Majo. IRA International Journal of Education and Multidisciplinary Studies (ISSN 2455-2526), 15(4), 154-159.doi: http://dx.doi.org/10.21013/jems.v15.n4.p7

(C) Institute of Research Advances.

This work is licensed under a Creative Commons Attribution-Non Commercial 4.0 International License subject to a proper citation to the publication source of the work.

Disclaimer: The scholarly papers as reviewed and published by the Institute of Research Advances (IRA) are the views and opinions of their respective authors and are not the views or opinions of the IRA. The IRA disclaims of any harm or loss caused due to the published content to any party.

Institute of Research Advances is an institutional publisher member of Publishers International Linking Association Inc. (PILA-CrossRef), USA. The institute is an institutional signatory to the Budapest Open Access Initiative, Hungary advocating the open-access of scientific and scholarly knowledge. The Institute is a registered content provider under Open Access Initiative Protocol for Metadata Harvesting (OAI-PMH).

The journal is indexed \& included in WorldCat Discovery Service (USA), CrossRef Metadata Search (USA), WorldCat (USA), OCLC (USA), Open J-Gate (India), EZB (Germany) Scilit (Switzerland), Airiti (China), Bielefeld Academic Search Engine (BASE) of Bielefeld University, Germany, PKP Index of Simon Fraser University, Canada.

This work was supported by the Yangtze University Teaching Research Project under Grant JY2017023 


\begin{abstract}
Based on the reality of English teaching in middle schools, this paper conducts a questionnaire survey on the students majoring in normal schools who have been teaching for three months and the current situation of English teaching in middle schools. Starting from reflecting on the curriculum setting of practical teaching in the training program of this major and combining with the analysis of the investigation of the present situation of English teaching in middle schools, we explore the reform and innovation mode of practical teaching in English Education major in universities, and put forward a comprehensive reform of practical teaching mode, i.e. the teaching mode of "covering the whole course of practical teaching", so as to promote the basic practice of encouraging students to complete practical teaching activities.
\end{abstract}

Keywords: Students majoring in the normal school, Practical teaching, English teaching in middle schools, Questionnaires survey, Reform and innovation mode

There have been many studies in College English teaching. Some scholars put forward three principles of action for building a "one-stop" system of foreign language teaching in primary schools, middle schools and universities [1]. Scholars also believe that the training mode of compound talents for majoring in normal schools can be composed of three modules, namely, basic knowledge and skills of English, teachers' literacy and teaching skills, and related subject knowledge [2]. Others put forward to build an experimental platform for training teachers' skills, optimize the experimental teaching content, and innovative training mode and evaluation method [3]. They all put forward their own views or practices in order to promote the teaching of English teachers in Colleges and universities. As we know, the main task of English education major is to train students to be comprehensive talents who serve English teaching posts, especially elementary education posts, and have certain professional skills, professional theoretical knowledge and professional teaching practice skills. "Educational practical ability is the total nuclear energy embodied in specific educational and teaching activities, and an organic entity consisting of multiple abilities. It mainly covers three basic fields: teaching, class management and educational scientific research. [4]

The essay intends to thoroughly probe into the reform and innovation of how to improve the practical teaching patterns in normal English major with the purpose of promoting the reform and innovation of practical teaching, expediting the improvement of normal English major's practical teaching in colleges and universities, fully perform and realize the colleges and universities' basic function of talent cultivation, scientific research, knowledge spreading and society serving, strengthening normal college students' ability in teaching practice, advancing the constant development practical teaching of normal English major.

\title{
I. The overview of the matter
}

We believe that the reform of the normal English major's training program ought to satisfy the needs and adapt to the development of society. There are two problems: one concerns the running scale, the other running quality. Therefore, we study with the focus on the reform and innovation of how to improve the practical teaching patterns in normal English major. Our research questions concerning it are as follows:

1. What is the orientation of the cultivation of normal English major professionals?

2. what are the qualifications to future teachers' teaching practice ability under today's basic education? 
3. From professional cultivation plan to actual teaching of all curricula, how to make them meet the needs of today's English basic teaching?

4. How to put the teaching pattern-the fully coverage of practical ability cultivation into effect?

\section{Research Methods}

In line with the above-mentioned problems, we adopted several methods to investigate and analyze the following aspects: the target in the talent training plan of English major oriented in education in our university and the existing issues observed by employing units toward the graduates and the difficulties they met with during the teaching practice.

\section{Literature Search}

Through analyzing the literature, we have a profound understanding of the orientation of training talents who are in English education major. Taking the School of Foreign Languages for example, for the sake of better fostering the comprehensive talents not only with integrated English proficiency but with outstanding teaching practice ability, our school has made some adjustment to the new training program, also in response to varying needs derived from the changing society toward the talents specialized in English education. To be more specific, by comparing the educational objectives before 2013 to those in 2017, the diverse expressions can be seen. Namely, the objective orientation prior to 2013 mainly focuses on cultivating "those teachers who can teach in high and secondary schools or other advanced professional personnel oriented in English [5]". However, the feedback of graduates' employment and the social demand for normal English talents indicate that most graduates are engaged in secondary education. Thus, the alteration of the objective orientation serves as fostering "extraordinary primary and middle school English teachers equipped with innovative consciousness as well as aptitude, the specialized talents in respect of teaching management and other advanced professional personnel oriented in English."

\section{Tracking investigations}

Through a follow-up survey on their professional and teaching skills in the schools where the graduates work, we have gotten a better understanding of the problems in the professional practice of them. At the same time, we have followed up the investigation of the graduates and on-the-job interns. There were 18 middle schools in the province, including 2 urban middle schools, 8 county middle schools and 8 township middle schools. According to the follow-up survey of teaching practice and teaching feedback after graduation, we have found that there were also problems with basic English skills and teaching practice ability in their teaching work. In terms of basic English skills, there are the following problems: 1) Basic English skills can't be used flexibly or comprehensively enough; 2) The relevant theoretical knowledge is not firmly grasped; 3) The various skills or knowledge mistakes often occur in the practical teaching. In terms of teaching practical skills, there are the following problems: 1) The teaching methods and strategies are not firmly mastered or flexibly applied; 2) The application of basic teaching links (such as organizational teaching, blackboard distribution, teacher-student interaction, etc.) is not natural and reasonable; 3) The expression function and art of asking questions are not proficient and skilful enough.

3.Questionnaire survey.

We especially surveyed students who have experienced a certain phase of teaching practice course 
ability training and have gone through a semester post teaching practice in a local middle school, knowing the feedback on the set of the English education courses and teaching model to adjust the teaching system and practice teaching pattern to the social demand of English education. The basic information following:(1) Respondents: Students in the post-practice in school of foreign languages(2014grade) (2) Objective: Knowing the states in students' professional ability and practice teaching ability. (3) Method: questionnaire survey. (4) Time: From September to December 2017 (5): Numbers: 72. This questionnaire is divided into 16 questions, aiming at the problem is students teaching skill and practice teaching ability. In fact, the questionnaire is distributed in 72 copies, and have collected 70 copies. Following is the result:

From the 16 questions, the most option has chosen from the surveyed students, reflecting the most remarkable problem. And from the specific situation what students think the most prominent aspects as follows: Firstly, students have basically known the professional skill, but also need to strengthen the practice teaching ability, and also need to improve the professional skills. Secondly, there is sufficient awareness and need in practice, teaching ability and professional skills. Thirdly, professional teaching skills many gained in teaching methodology course and teaching practice. Fourthly, lacking the experience in teaching and ability training in scientific research. Fifthly, having a unified understanding of the assessment of professional practice ability.

\section{Practical teaching mode's reform and innovation}

According to the survey mentioned above, to meet and adapt to society's demands for the speciality of English teachers, we need to adjust and reform the present teaching mode. Thus, we conclude the actual situation of the teaching investigation and propose a new teaching mode — The Full Coverage of Practical Teaching, which will be implemented progressively in the teaching towards the speciality of English teachers.

\section{The main content of the "The Full Coverage of Practical Teaching"}

To implement the main content of the "The Full Coverage of Practical Teaching" is to gradually carry out the full-course professional and practical skill training during their four years of college study. The "full-coverage" contains two aspects: One is to carry out the teaching skill training each term according to the schedule. The contents of the training, following the principals of gradual progress and from single to comprehensive, aim to improve students' teaching skill. Another is to revise the teaching plans in a part of professional courses (Some comprehensive skills application courses like Comprehensive English、Oral Class、Extensive Reading etc. and some Upper-Divisions like British and American Literature、 Linguistic Class、Translation Class and Teaching Methodology etc.). And to set up a certain proportion (8:2 or 7:3) of classroom teaching modules so as to make students be appropriately trained in different levels of practical ability. For example, presenting the teaching contents to them and communicating the teaching points of views with them based on their comprehension. In order to highlight the cultivation of the speciality of English teachers' comprehensive application abilities, we plan to add some supplementary courses related to teaching practical skill. Such as the Writing and Stick Figure Drawing Skill of Teachers' (in freshman year)、 the Art of Teaching Questioning(in sophomore) 、Skills and Strategies in Language Communication (in sophomore)、 the Design of Professional Practice Activity (in sophomore)、 the Design of Classroom Instruction (in junior year)、Frontiers in Educational Science (in junior year)、 the Report of Research (in junior year)、 the Basis of Teaching and Research Methods (in junior year) etc., and to carry out various 
Professional extracurricular activities such as the Research Group of English Learning Methods (in freshman year)、 the Research Group of Primary and Secondary School English Teaching Materials (in sophomore year)、 the Research Group of Primary and Secondary Schools' Teachers' Qualities (in sophomore year)、 the Research Group of Primary and Secondary School Classes (in sophomore year)、 the Research Group of Teaching Links (in junior year)、Study Group on Cultural Differences Between English and Chinese (in junior year) etc. We hope these contents can active and promote students' professional skills as well as their teaching skills from every aspect.

\section{Reform teaching methods and teaching means}

Starting from the mode of 'practical teaching covers the whole process,' we have adjusted teaching methods and teaching means accordingly. The so-called 'full coverage' means begin with the freshmen enters the school, professional curriculum learned by the combination of classroom presentation and group discussion. That is, a teaching mode that implementing presentation before practice. At first, the teacher imparts professional theories and knowledge and then divides the whole class into groups for special training, discussion and the summary. Each student has no less than 5 practice opportunities in professional class in a semester. At the same time, it needs to video the whole process of students' practical activities with the help of electronic equipment, and later combined the way of playback, peer mutual evaluation and teacher comments. This kind of teaching mode has been applied to some basic skills course, such as 'integrated English' and 'spoken English', and attempted to be applied to professional curriculum with strong theoretical content. (Such as Basic linguistics, British and American literature etc.) in order to change the teaching mode of only imparting knowledge and let students take the initiative to participate in the research and discussion of course content. We have implemented this mode in the above course and achieved good teaching results.

\section{Strengthen the pass of teacher education's exam}

In order to realize "the full coverage of practical teaching" and strengthen the improvement of teaching quality, we set the assessment content of English Education majors in four-year undergraduate course learning:

1) Planned courses: English phonetics (grade1 assessment/16 credit hours),Spoken English(grade2 assessment/36 credit hours),Middle school English textbooks (grade3 assessment/36 credit hours),Middle school English teaching Methods (grade3/36credit hours);

2) Unplanned courses: English trail teaching (grade3 assessment), Mandarin (assessment before graduation )

Through the study and assessment of these contents, we hope that students' basic English skills and teaching practice skills can be greatly improved, and gradually meet the requirements of teacher education. In addition, students are encouraged to focus on teaching practice ability and English teaching status analysis as the main content in their graduation thesis design, and students are encouraged to collect first-hand data during their teaching practice to conduct relevant English teaching investigation and research.

\section{Conclusions:}

Through the investigation of teacher education practice and the training program of the teaching process, we have a clear understanding of the above problems. First of all, we have made it clear that the talent training program for normal English major is mainly to train excellent primary and secondary 
school English teachers, English teaching management professionals and other advanced English talents with innovative consciousness and ability. Second, basic education today requires the future teachers in their teaching practice ability to basically master the professional skills, and still need to strengthen the teaching practice ability; Thirdly, from the professional training program to the teaching of various courses, we highly promote and implement the teaching mode of "practice teaching covering the whole process", and strengthen the improvement of practice teaching skills by various means while learning professional skills, so as to meet the needs of basic English teaching today. Fourth, the teaching mode of "practice teaching covering the whole process" should be implemented in different ways in all levels and types of teaching. Of course, the assessment and evaluation system should be adjusted accordingly to the changes in the training program. Moreover, with the update of practice teaching mode, the assessment and evaluation system also need to be improved appropriately.

\section{References:}

[1]. Wang Jisheng.Scientific Connotation and Discipline Construction of Higher Education [J].Higher Education Research, 2009 (5).

[2]. Sun Weimin. Vigorously Strengthening Practical Teaching to Improve the Quality of Talent Cultivation [J].China University Teaching, 2010 (3).

[3]. Xu Zhuoju. Discourse analysis: Part of the Study of Language Ability [J].Contemporary Linguistics, 2011(3).

[4]. Bao Hongxia, Wang Tiefeng, Liu Yang.On the Construction of Relatively Complete Practical Teaching System [J].Journal of Inner Mongolia Institute of Finance and Economics, 2012 (12).

[5]. The Professional Cultivation Program for Yangtze University Undergraduates in 2013. Yangtze University Academic Affairs Office.

[6]. The Professional Cultivation Program for Yangtze University Undergraduates in 2017. Yangtze University Academic Affairs Office. 